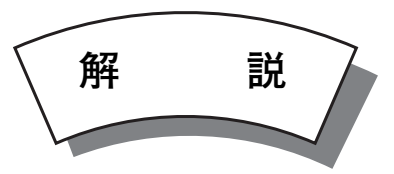

\title{
摩擦攪拌プロセッシングを利用したポーラスアルミニウムの作製
}

\section{Fabrication of Porous Aluminum by Friction Stir Processing}

\author{
半谷禎 彦*
}

Yoshihiko HANGAI

Key Words: Foam, Friction Stir Welding, Functionally Graded Materials, Sandwich Structure, Sintering

\section{1. 緒 言}

気孔がアルミニウム $(\mathrm{Al})$ 中に多く存在しているポーラ ス $\mathrm{Al}$ は、軽量性・衝撃吸収性・防音性・断熱性等に優れ た素材である。ポーラス $\mathrm{Al}$ の作製方法は様々提案されて いるが 1)-5)、本稿では摩擦攪拌プロセッシング (friction stir processing, FSP) を利用したプリカーサ法とスペーサー法を 紹介する。

プリカーサ法は、Al 中に発泡剂粉末を均一に分散したプ リカーサをあらかじめ作製し、そのプリカーサを加熱する ことで、発泡剤の分解によりガスを発生させ、軟化した $\mathrm{Al}$ 中に気孔を生成する方法である。従来、プリカーサは $\mathrm{Al}$ 粉 末と発泡剂粉末を混合焼結する粉末治金法により作製され てきた ${ }^{6-8)}$ 。著者らは、FSP を利用することで Al 板材から プリカーサを作製できることを見出した ${ }^{9), 10)}$ F FSP の強力 な攪拌作用を利用して $\mathrm{Al}$ 板材中に発泡剂粉末を混合しプリ カーサを作製するものである。プリカーサ法により作製し たポーラス $\mathrm{Al}$ は、気孔 1 つ 1 つが閉空間となり独立に存 在するクローズドセル構造を有しており、Fig. 1 に示すよ うに、水にも浮くような $\mathrm{Al}$ 構造体となる。また、FSP は摩 擦攪拌接合 (friction stir welding, FSW) を基にした方法であ

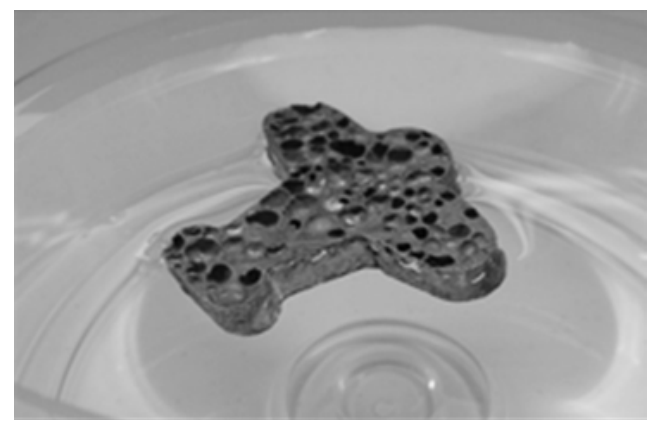

Fig. 1 Ultralight porous Al.
るため、FSP 中に接合も行うことができ、ポーラス $\mathrm{Al}$ の複 合化も容易である。本稿ではその一例として、傾斜機能ポー ラス $\mathrm{Al}$ と、ポーラス $\mathrm{Al}$ をコア材としたサンドイッチパネ ルを紹介する。

スペーサー法は、Al 粉末とスペーサー粉末を混合焼結 し、得られた焼結体からスペーサーを取り除くことで、気 孔を生成する方法である ${ }^{11), 12)}$ 。著者らは、混合粉末の焼結

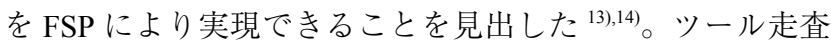
時に発生する摩擦熱と押込み荷重により焼結を行うもので ある。スペーサー法により作製したポーラス $\mathrm{Al}$ は、それぞ れの気孔がつながった連通気孔となっておりオープンセル 構造を有している。ツールを走査させるだけで焼結が可能 であるため、任意の大きさのポーラス $\mathrm{Al}$ が得られる。本稿 では、マルチパス FSPにより作製したポーラス $\mathrm{Al}$ 板を紹 介する。

\section{FSP を利用したプリカーサ法}

2.1 ポーラス $\mathrm{Al}$ 作製方法 ${ }^{9), 10)}$

Fig. 2 に FSP を利用したプリカーサ法によるポーラス $\mathrm{Al}$ 作製方法の概略を示す。まず、Fig. 2(a)に示すように、2 枚のアルミニウム板材の間に発泡剂粉末（本研究では、水 素化チタン、 $\mathrm{TiH}_{2}$ ) を散布し積層板とする。次に、Fig. 2(b)、(c) に示すように、積層板の発泡剂粉末散布領域全体 に対して FSP を行う。プローブ長さは通常の FSW と同様、 バックプレートに接触しない程度に、積層板の厚さより少 しだけ短いツールを使用し、板厚方向に均一に発泡剂粉末 が攪挥されるようにする。また、Fig. 2(c)に示すようにマ ルチパス FSPを適用し、大きなプリカーサを作製するた めに複数列のマルチパス FSP、および発泡㓮粉末を均一に 混合するために同一個所を複数回攪拌するマルチパス FSP の両方を行う。その後、Fig. 2(d) に示すように、FSPによ り攪拌された領域から機械加工によりプリカーサを切り 出し、得られたプリカーサを加熱発泡させることで、Fig.

* 群馬大学 大学院理工学府 知能機械創製部門（～３76-8515 群馬県桐生市天神町 1-5-1）

Division of Mechanical Science and Technology, Faculty of Science and Technology, Gunma University

(1-5-1 Tenjin-cho, Kiryu-shi, Gunma, 376-8515 Japan) 
(a) Al

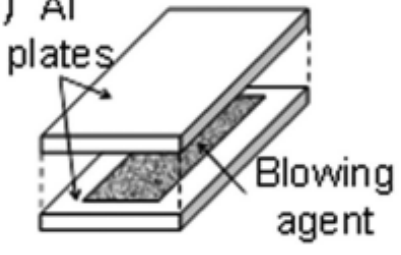

(b)

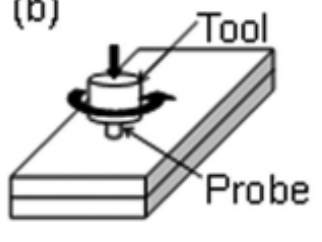

(c)

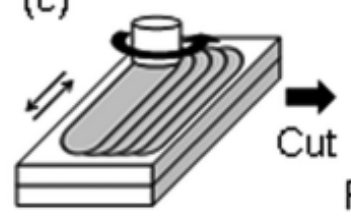

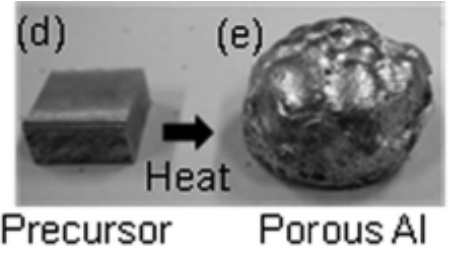

Fig. 2 Schematic illustration of fabrication process for porous Al by FSP (precursor process).

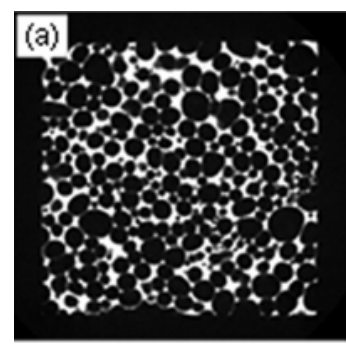

$10 \mathrm{~mm}$

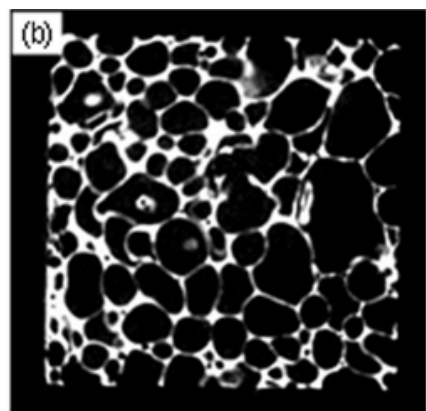

Fig. 3 Porous Al fabricated using Al alloy die-castings (a) without blowing agent and (b) with blowing agent ${ }^{17}$.

2(e)に示すようなポーラスアルミニウムを得る。

\section{2 発泡剂不使用ポーラス $\mathrm{Al}^{15)-17)}$}

$\mathrm{Al}$ 合金ダイカスト製品は、自動車部品等に広く用いられ ているが、内部にある量のガスが混在している。このガス は、離型剤や潤滑剤が $\mathrm{Al}$ 溶湯と反応してガス化したものや、 金型内に存在していた空気などに由来している。著者らは、 このガスを発泡源として利用することで、発泡郕を用いる ことなくポーラス $\mathrm{Al}$ が作製できることを見出した。 $\mathrm{Al}$ 合 金ダイカスト中のガスによる気孔の生成はブリスター試験 などで知られているが、偏析しておりそのままではポーラ ス $\mathrm{Al}$ としては利用できない。そこで、 $\mathrm{Al}$ 合金ダイカスト 板材にFSP を行うことで、ガスが均一に混合したプリカー サとなり、均一な気孔分布を持つポーラス $\mathrm{Al}$ が作製できる。 作製方法の概略は Fig. 2 に示す工程とほぼ同様であるが、 用いる板材が $\mathrm{Al}$ 合金ダイカスト板材である点、および発泡 剂粉末を使用しない点に特徵がある。

Fig. 3 に Al 合金ダイカストから発泡剂を使用せずに作製 したポーラス $\mathrm{Al}$ と、同じ $\mathrm{Al}$ 合金ダイカストに発泡剤を混 合して作製したポーラス $\mathrm{Al}$ の X 線 CT 断層画像を示す ${ }^{17) 。 ~}$ 発泡剂を使用しないポーラス $\mathrm{Al}$ は、発泡剤を使用したポー ラス $\mathrm{Al}$ と比較して、細かい気孔となっている。これは、 $\mathrm{Al}$ 板材中に含有できるガス量には限界があり、発泡剤を用い る場合に比べると、発泡に使えるガス量が少ないためと考 えられる。また、 $\mathrm{Al}$ 合金ダイカスト板材中に含まれるガス
量と作製されるポーラス $\mathrm{Al}$ の気孔率（ポーラス $\mathrm{Al}$ 中の気 孔の体積割合：気孔率が高いほど密度が低い）には相関が あるが ${ }^{15)} 、 \mathrm{Al}$ 板材中に含有できるガス量の限界により、気 孔率 $90 \%$ 程度以上の高気孔率ポーラス $\mathrm{Al}$ を作製すること は困難である。

\section{3 傾斜機能ポーラス $\mathrm{Al}^{18)-21)}$}

Fig. 4 に傾斜機能ポーラス $\mathrm{Al}$ 作製法の概略を示す。ここ では、工業用純 $\mathrm{Al}$ の $\mathrm{A} 1050$ 板材と $\mathrm{Al}-\mathrm{Mg}-\mathrm{Si}$ 系 $\mathrm{Al}$ 合金の A6061 板材の組合せによるA1050/A6061 傾斜機能ポーラス $\mathrm{Al}$ の作製例を示す。まず、FSPにより A1050 および A6061 それぞれのプリカーサを Fig. 2 に示した方法で別々に作製 する（Fig. 4(a)、(b))。次に、Fig. 4(c) に示すように、それ ぞれ作製したプリカーサをFSWにより突合せ接合し、そ れを加熱発泡させることで、A1050/A6061 傾斜機能ポーラ ス $\mathrm{Al}$ が得られる。ここで、Fig. 4(a)、(b)のように別々に FSP を行わず、あらかじめ Fig. 4(c)のように並べておいて FSP と FSW を同時に行うことも可能であるが、接合部近傍 の攪拌回数が多くなるため、A1050 とA6061 の境界領域（混 合領域）が若干広くなる。

Fig. 5(a)に作製したA1050/A6061 傾斜機能ポーラス Al の外観を示す ${ }^{18)}$ 。外観からは、A1050 層とA6061 層はほと んど見分けがつかないが、上層がA1050、下層がA6061 と なっている。他にも、同一の $\mathrm{Al}$ 合金を用いて混合する発泡 剤量を調整することにより、気孔形態のみが恋化する傾斜 機能ポーラス Al も作製することができる。Fig. 5(b)、(c) は、 Fig. 3 で示した発泡剂を混合しないポーラス $\mathrm{Al}$ (0 mass\%) と混合したポーラス $\mathrm{Al}$ (1 mass\%) を 2 層 ${ }^{19), 20) 、 あ る い は ~} 3$ 層 ${ }^{21)}$ に組み合わせたものである。このような傾斜機能ポー ラス $\mathrm{Al}$ は、圧縮変形時に低強度層（A1050層や発泡剂 1 mass \% 層）から変形が開始し、ある程度変形した後、高強 度層（A6061 層や発泡剂 0 mass\% 層）の変形が開始すると いった変形制御が可能である。また、それぞれの層の変形 時に、それぞれの層の力学特性が発現するため、複数の力 学特性を 1 つのポーラス $\mathrm{Al}$ で実現でき、力学特性の制御も 可能である。

2.4 サンドイッチパネル 22-25)

ポーラス $\mathrm{Al}$ は優れた圧縮衝撃吸収特性を有するが、気孔 
(a)

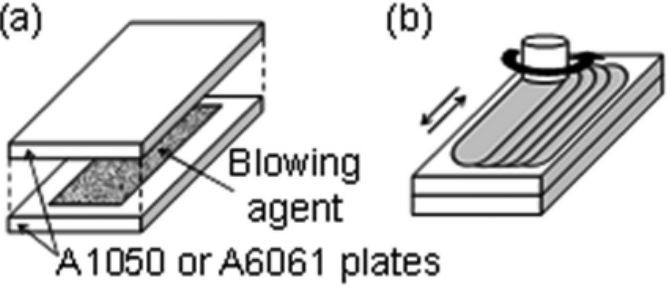

(c)

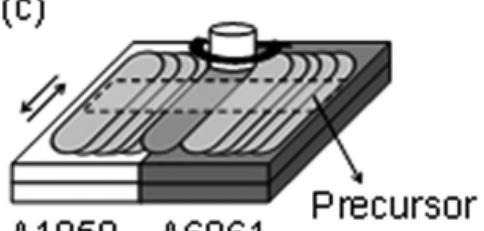

A.1050 A6061

Fig. 4 Schematic illustration of fabrication process for functionally graded porous Al by FSP (precursor process).

(a)

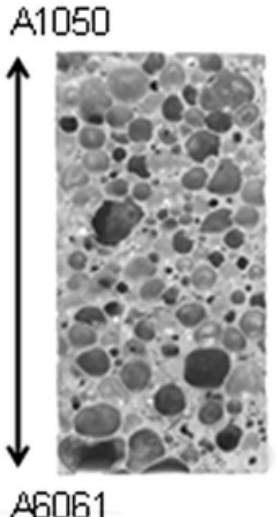

(b)

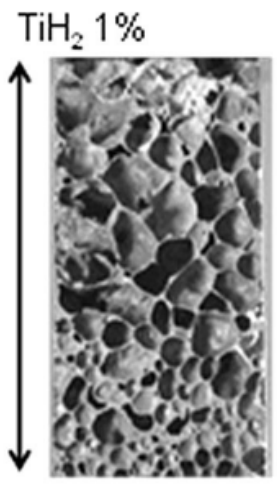

$\mathrm{TiH}_{2} \mathrm{O} \%$ (c) $\mathrm{TiH}_{2}$

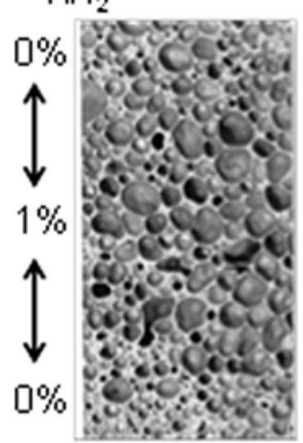

$10 \mathrm{~mm}$

Fig. 5 (a) A1050/A6061 functionally graded porous $\mathrm{Al}^{18)}$.

(b) Two layered functionally graded porous $\mathrm{Al}$ varying porosity ${ }^{19}$.

(c) Three layered functionally graded porous $\mathrm{Al}$ varying porosity ${ }^{21)}$.

(a) Al

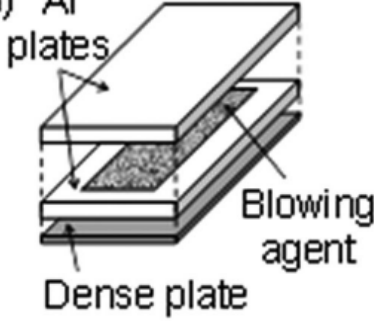

(b)

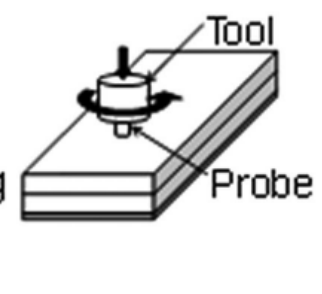

(c)

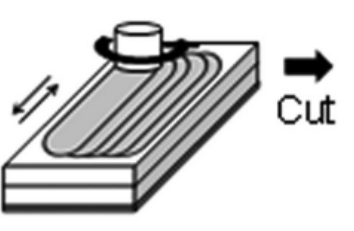

(d)

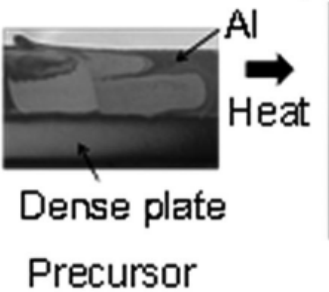

(e)

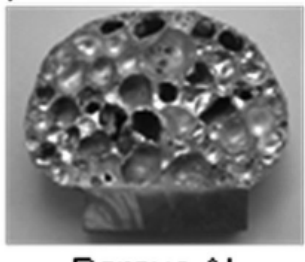

Porous Al

Fig. 6 Schematic illustration of fabrication process for porous Al/dense plate composite by FSP (precursor process).

が多くを占め $\mathrm{Al}$ 部の断面積が少ないことから、引張強度や 曲げ強度は低いといった問題があった。これを解決するた めに、緻密板材と組み合わせた複合化が有効と考えられる。

Fig. 6 にポーラス $\mathrm{Al}$ と緻密板材との複合化の手順を示 す。Fig. 2 に示した $\mathrm{Al}$ 板材に発泡剂を混合する工程と、ほ ぼ同工程で作製することができるが、Fig. 6(a) に示すよう に $\mathrm{Al}$ 板材積層板の下に緻密板材となる板材をバックプレー トのように敷いておく点に特徵がある。Fig. 6(b)、(c) に示 すFSP の際に、緻密板材の表面をわずかにプローブ先端で
擦らせることで (本研究の場合、ツール先端の押込み量 0.2 $\mathrm{mm}$ 程度)、Fig. 6(d) に示すようにプリカーサの作製と同時 にプリカーサと緻密板材との接合も達成できる。これを加 熱発泡させることで、Fig. 6(e) に示したような金属接合に よる複合部材を作製することができる。この加熱発泡の際 に、2つのプリカーサを対面させて発泡させることで、Fig. 7 に示すようなサンドイッチパネルを作製することができ る。ポーラス $\mathrm{Al}$ をコア材としたサンドイッチパネルにより、 水に浮くような軽量性を維持したまま、引張強度や曲げ強 


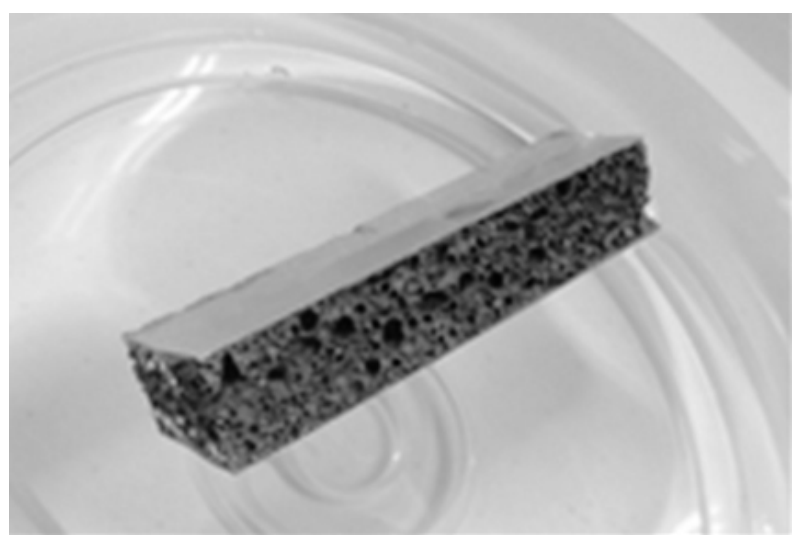

Fig. 7 Ultralight porous Al/Al plates sandwich panel.

度の向上を達成することができる。

従来サンドイッチパネルは、あらかじめ作製しておいた ポーラス $\mathrm{Al}$ に接着剤で緻密板材を接着することで作製され

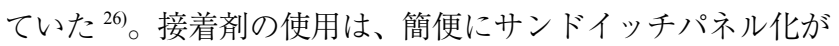
可能であるが、接着工程が不可欠であるとともに、耐久性や リサイクル性が懸念される。また、金属接合によるサンドイッ チパネル化を実現する方法として、あらかじめ作製しておい たプリカーサと緻密板材をクラッド接合し、それを加熱発泡 させる方法が提案され実用化されているが 8),27)、プリカーサ と緻密板材とのクラッド接合工程が増える。FSP の利用によ りプリカーサの作製と同工程で緻密板材との接合が可能と なれば、工程数を削減でき、低コスト化につながると期待さ れる。

Fig. 8 にポーラス $\mathrm{Al}$ と緻密鋼板のサンドイッチパネルに おける接合界面の組織を示す。プリカーサの段階では FSW により数 $\mu \mathrm{m}$ の金属間化合物が生成するが ${ }^{28)}$ 、加熱発泡工 程により、数十 $\mu \mathrm{m} の \mathrm{Fe}_{2} \mathrm{Al}_{5}$ や $\mathrm{FeAl}_{3}$ などの金属間化合物 層が生成する ${ }^{22)}$ 。脆い金属間化合物層の生成は界面強度を 低下させることが懸念される。Fig. 9 にポーラス部の気孔 率が $79.6 \%$ のンドイッチパネルの引張試験の様子を示 す ${ }^{22)}$ 。破断はポーラス $\mathrm{Al}$ 部で起こっており、ポーラス $\mathrm{Al}$ と緻密板材の界面では、き裂などの損傷は見られない。こ れは、本手法で作製可能なポーラス $\mathrm{Al}$ 部の気孔率 55-85 $\%$ のサドイッチパネルのうち、気孔率が $65 \%$ 以上の場 合全てについて同様の傾向を示しており、数十 $\mu \mathrm{m}$ の金属 間化合物層が生成しても、強固な界面を有するサンドイッ チパネルが作製できる ${ }^{23)}$ 。また、緻密板材が $\mathrm{Al}$ 板材の場合、 気孔率 50-80\%のもの全てについて同様の傾向であり、強 固な界面を有するオールアルミニウムのサンドイッチパネ ルが作製できる ${ }^{24)}$

\section{FSP を利用したスペーサー法 ${ }^{13), 14)}$}

Fig. 10 にFSPを利用したスペーサー法によるポーラス

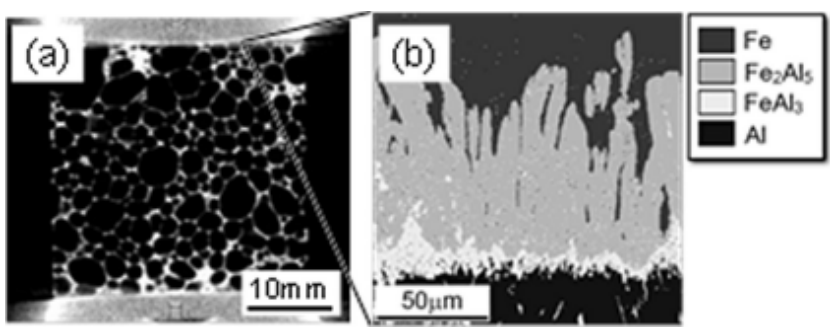

Fig. 8 (a) X-ray $\mathrm{CT}$ image of porous $\mathrm{Al} / \mathrm{SPCC}$ steel plates sandwich panel. (b) Microstructure of interface between porous Al and SPCC steel plate ${ }^{22)}$.
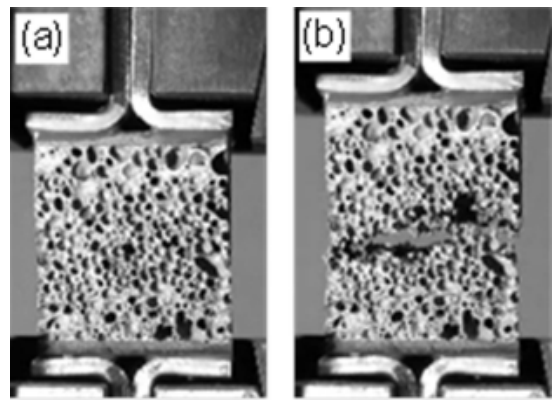

Fig. 9 Tensile test of porous Al/SPCC steel plates sandwich panel of (a) initial state and (b) final state ${ }^{22}$.

$\mathrm{Al}$ 作製方法の概略を示す。Fig. 10(a)に示すように、まず 作製するポーラス $\mathrm{Al}$ と同じ大きさの貫通穴を空けた金属 板 C（本研究では熱伝導性に優れる銅板）を用意する。そ の貫通穴に、 $\mathrm{Al}$ 粉末とスペーサー粉末（本研究では、水へ の溶解度の高い塩化ナトリウム $(\mathrm{NaCl})$ 粉末) の混合粉末を 投入し、上板 $\mathrm{A}$ と $\mathrm{B}$ をかぶせる。上板を使用することで、 ツール走査中の振動で混合粉末が貫通穴から出ないように するとともに、ツールの回転力により気孔の形状が変形す ることを防ぐ。次に、Fig. 10(b) に示すように、その上か らッール走査を行い、発生する摩擦熱と押込み荷重により 粉末の焼結を行う。また、幅広のポーラス $\mathrm{Al}$ を作製するた めに、Fig. 10(c) に示すように、マルチパス FSP を適用し 複数列および同一個所を複数回のツール走査を行う。最後 に、Fig. 10(d) に示すように、焼結体から $\mathrm{NaCl}$ を水洗によ り除去することで、 $\mathrm{NaCl}$ が存在していた個所が気孔となり、 Fig. 10(e) に示すように、金属板 C の貫通穴と同じ大きさ のポーラス $\mathrm{Al}$ が得られる。

Fig. 11 に実際に得られたポーラス $\mathrm{Al}$ を示す ${ }^{14)}$ 。各個所 から切り出した試験片の、X 線 CTによる気孔観察と圧縮 試験から、どの位置においても、ほぼ均一な気孔形態とほ ぼ同様の力学特性を有するポーラス $\mathrm{Al}$ 板が得られることが 分かっている。また、圧縮試験時に焼結不足による崩れる ような変形挙動がほとんど見られないことから、試料全体 
(a)

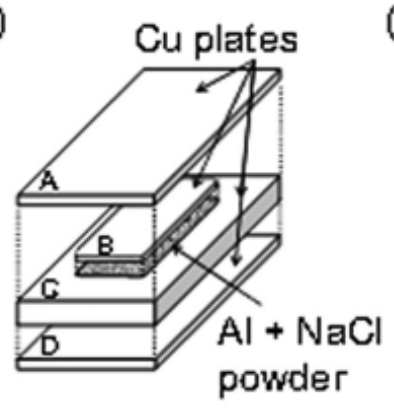

(b)

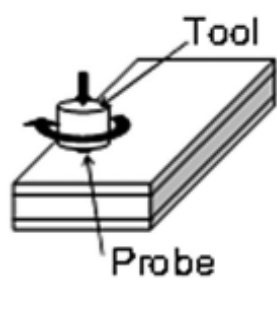

(c)

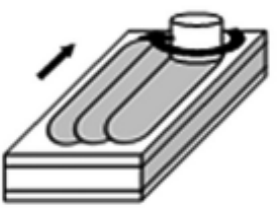

(d)

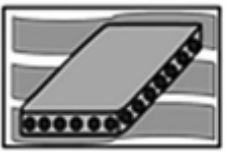

Dissolution (e)

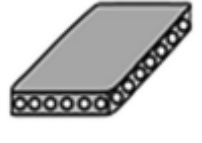

Porous Al

Fig. 10 Schematic illustration of fabrication process for porous Al by FSP (spacer process).

\section{Tool traversing direction}

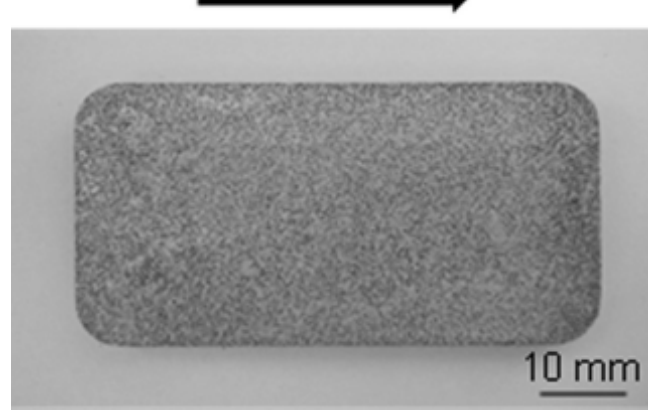

Fig. 11 Porous Al plate fabricated by multi-pass FSP (spacer process) ${ }^{14)}$.

で均一に同程度の焼結が可能である。更に、従来の加熱炉 などを使用して焼結し作製したポーラス $\mathrm{Al}$ の圧縮特性と ほぼ同様の傾向を示すことから、十分な焼結が可能である 14)。

本手法は、焼結が必要な個所に限定して摩擦熱により加 熱するため、省エネルギーな手法であると考えられる。ま た、通常の加熱炉を用いた従来法と比較して、短時間のプ ロセスで焼結が可能であるため、生産性および省エネル ギー性に優れた手法であると期待される。 $\mathrm{Al}$ 以外にも、ツー ルの垂直押込みのみによるスポットFSP で銅のポーラス化 も可能であることが分かっている ${ }^{29)}$ 。本手法で作製された ポーラス銅は、オープンセル構造を有し比表面積が大きい ため、ヒートシンクなどへの応用も期待される。

\section{4. 結 言}

本稿では、FSP を利用したポーラス $\mathrm{Al}$ の作製について 紹介した。FSPをプリカーサ法に適用することで、FSPの 強力な攪拌力を用いて、 $\mathrm{Al}$ 板材中に発泡剂粉末を均一に分 散させたプリカーサが作製できる。FSP を利用することで、 種々の特性を有する $\mathrm{Al}$ 板材からプリカーサを作製できると ともに、FSWを用いてそれらプリカーサを組み合わせ接合
することで、傾斜機能化できる。板材からポーラス $\mathrm{Al}$ が 作製できるため、低コスト化が図られると考えられる。課 題として、粉末の攪拌はツールの摩耗を促進するため、耐 久性のある非消耗ツールの開発が待望される。また、攪拌 力を大幅に向上可能なツールが開発できれば、ツール走査 の高速化やッール走査回数の低減などが図られ、生産性の 向上が期待できる。FSP をスペーサー法に適用することで、 FSP の摩擦発熱現象と押込み荷重を用いて、ツール走査の みで粉末の焼結が可能で、ポーラス $\mathrm{Al}$ が簡便に作製できる。

本特集号において、FSP の最新技術が紹介されているが、 FSP 技術の進歩をポーラス $\mathrm{Al}$ の作製に取り入れることで、 更なる生産性の向上や低コスト化につながることが期待さ れる。本稿が、FSP の使い方の 1 つとして、読者の皆様の 参考になれば幸いであるとともに、本特集号を契機として、 FSP 技術が益々進展することを願っている。

\section{謝 辞}

本研究の一部は、大阪大学接合科学研究所「接合科学共 同利用・共同研究拠点」共同研究員制度の一環として行わ れ、機能評価研究部門 - 機能性診断学分野の藤井英俊先生、 上路林太郎先生、孫玉峰先生、森貞好昭先生には、有意義 なディスカッションやご助言をいただきました。ここに記 して、厚く感謝いたします。

\section{引用文献}

1) J. Banhart: Prog. Mater. Sci. 46 (2001) 559-632.

2) 小橋眞 : 軽金属 55 (2005) 327-332.

3) 中嶋英雄監修：マクロおよびナノポーラス金属の開発最前線、 (シーエムシー出版、東京、2011)

4) 金武直幸、小橋眞：軽金属 62 (2012) 122-134.

5) J. Banhart: Adv. Eng. Mater. 15 (2013) 82-111.

6) F. Baumgartner, I. Duarte, J. Banhart: Adv. Eng. Mater. 2 (2000) 168-174.

7) 小橋眞、棚橋伸也、金武直幸 : 軽金属 53 (2003) 427-432.

8) J. Banhart, H. W. Seeliger: Adv. Eng. Mater. 14 (2012) 1082-1087.

9) 半谷禎彦、宇都宮登雄：日本金属学会誌 73 (2009) 131-133. 
10) Y. Hangai, T. Utsunomiya, M. Hasegawa: J. Mater. Process. Technol. 210 (2010) 288-292.

11) Y. Y. Zhao, D. X. Sun: Scr. Mater. 44 (2001) 105-110.

12) 袴田昌高、馬渕守：軽金属 62 (2012) 313-321.

13) Y. Hangai, K. Zushida, O. Kuwazuru, N. Yoshikawa: J. Mater. Process. Technol. 214 (2014) 1721-1727.

14) 半谷禎彦、圖子田幸佑、桑水流理、吉川暢宏：日本機械学会 論文集 81 (2015) 14-00600.

15) Y. Hangai, H. Kato, T. Utsunomiya, S. Kitahara: Metall. Mater. Trans. A 41 (2010) 1883-1886.

16) 半谷禎彦、加藤弘規、宇都宮登雄、北原総一郎：日本金属学 会誌 74 (2010) 697-699.

17) 半谷禎彦、高橋和也、加藤弘規、宇都宮登雄、北原総一郎、 桑水流理、吉川暢宏：日本金属学会誌 75 (2011) 465-467.

18) Y. Hangai, K. Saito, T. Utsunomiya, O. Kuwazuru, N. Yoshikawa: Mater. Sci. Eng. A 613 (2014) 163-170.

19) Y. Hangai, K. Takahashi, T. Utsunomiya, S. Kitahara, O. Kuwazuru, N. Yoshikawa: Mater. Sci. Eng. A 534 (2012) 716-719.

20) Y. Hangai, K. Takahashi, R. Yamaguchi, T. Utsunomiya, S. Kitahara,
O. Kuwazuru, N. Yoshikawa: Mater. Sci. Eng. A 556 (2012) 678684.

21) Y. Hangai, H. Kamada, T. Utsunomiya, S. Kitahara, O. Kuwazuru, N. Yoshikawa: Mater. Trans. 54 (2013) 1268-1273.

22) Y. Hangai, N. Ishii, S. Koyama, T. Utsunomiya, O. Kuwazuru, N. Yoshikawa: Mater. Trans. 53 (2012) 584-587.

23) T. Utsunomiya, N. Ishii, Y. Hangai, S. Koyama, O. Kuwazuru, N. Yoshikawa: Mater. Trans. 53 (2012) 1674-1679.

24）宇都宮登雄、石井伸幸、半谷禎彦、小山真司、北原総一郎、 桑水流理、吉川暢宏：日本金属学会誌 77 (2013) 385-390

25) Y. Hangai, H. Kamada, T. Utsunomiya, S. Kitahara, O. Kuwazuru, N. Yoshikawa: J. Mater. Process. Technol. 214 (2014) 1928-1934.

26) 三好鉄二、濱田猛、金橋秀豪：R\&D 神戸製鋼技報 57 (2007) 95-100.

27) J. Banhart, H. W. Seeliger: Adv. Eng. Mater. 10 (2008) 793-802.

28) Y. Hangai, S. Koyama, M. Hasegawa, T. Utsunomiya: Metall. Mater. Trans. A 41 (2010) 2184-2186.

29) Y. Hangai, K. Zushida, H. Fujii, R. Ueji, O. Kuwazuru, N. Yoshikawa: Mater. Sci. Eng. A 585 (2013) 468-474. 